\title{
The Effect of Spirit at Work and Compensation toward Employee Performance in PT. Arista Auto Lestari Medan
}

\author{
Teddi Pribadi ${ }^{1}$, Ihsan Effendi ${ }^{2}$, Wan Suryani $^{3}$ \\ 1,2,3 Jurusan Manajemen Universitas Medan Area \\ teddipribadi71@gmail.com
}

\begin{abstract}
The purpose of this study was to determine the "Effect of Work Spirit and Compensation on Employee Performance at PT. Arista Auto Lestari Medan ". The type of data used is associative, which is a study that asks the relationship between two variables. The population in this study were all employees at PT. Arista Auto Lestari Medan as many as 65 people. Data collection techniques in the form of distributing questionnaires to office employees at PT. Arista Auto Lestari Medan. Data analysis techniques using validity and reliability, hypothesis testing, statistical tests using multiple linear analysis models using multiple linear analysis models and determination tests. The results of the $t$ test can be seen that the $t$ count on the morale variable is 4.147 greater than t table of 1.689 with a probability of $t$ that is sig 0.004. Based on these values, the morale variable has a positive and significant effect on performance variables and the value of $t$ arithmetic oversight is 6,649 greater than t table of 1,689 with a sig level of 0,000 smaller than the significance limit of 0.005, the partial compensation variable has a positive and significant effect on performance variable. Based on the results of the F test, the F value of 42.567 is greater than the F table of 3.27, which means that morale and compensation simultaneously have a positive and significant effect on performance variables. The $R$ Square value obtained is 0.727 . This figure shows that $72.7 \%$ of performance (the dependent variable) can be explained by morale and compensation. The remaining $27.3 \%$ is influenced by other factors not explained in this study.
\end{abstract}

Keywords

power; resistance; ideology

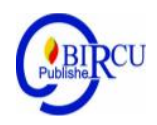

\section{Introduction}

In life, motivation has a very important role because motivation is an entity causing, channeling, and supporting human behavior, so that they want to work hard and enthusiastically to achieve the optimal results. Likewise, in the world of work, motivation plays an important role in achieving the organizational goals. Motivation is important because, by having this motivation, it is expected that each individual of employee is willing to work hard and enthusiastically to achieve high work productivity. Motivation comes from the Latin word "movers" meaning "impulse or driving force". This motivation is given to humans, especially to subordinates. Related to this, what is meant by motivation is to question how to encourage the enthusiasm of subordinates' work, so that they want to work hard by giving all their abilities and skills to realize organizational goals. Motivation is the whole process of giving encouragement to subordinates to work in such a way so that they want to work with sincerity, and the achievement of efficient and economical organizational goals can be achieved. (Siagian in kuswati, 2019) 
One of the challenges faced by the company is the problem of human resources related to performance improvement. This is the most difficult aspect of the company related to how to make employees work efficiently. Performance is the work of individuals or groups in an organization in order to achieve organizational goals and will later be used as a basis for evaluating whether or not the targets and objectives of the organization are achieved. In achieving the targets and objectives of the organization is not easy, both government-owned or private-owned organizations. In maintaining and increasing the productivity of a company, the role of human resource management is very important in terms of striving for workers to be willing and able to provide the best possible work performance. In this case the company is obliged to pay attention to the needs of its employees both material and non material. The manifestation of attention, effort and encouragement that can be done by the company towards its employees, one of which is to carry out the promotion of an objective and fair position and the right placement.

The morale factor must be known by the leaders or managers of the company because it is important for the success of a business. Said to be important for the success of a business because morale can affect employee performance. In addition to morale, the compensation factor also improves employee performance. compensation is one form of improving employee performance, through compensation also increases employee morale that will increase so that with high performance will achieve the desired company goals and set. In an effort to achieve these goals, managers or leaders must strive to create high morale and appropriate compensation so that performance increases as desired. High performance will be accompanied by efficient and effective activities that will create profits for the company.

PT. Arista Auto Lestari Medan which is a company engaged in the field of Automotive. High morale is expected to increase the company's goals that bring in profits.

Based on previous surveys conducted by researchers of the company, the phenomenon of the problems faced by PT. Arista Auto Lestari Medan in terms of morale is the lack of employee morale due to the lack of motivation of employees at work, they look relaxed during working hours, chatting with each other, there are also employees sleeping during working hours. The decline in morale makes employee performance here decreases. In addition to the issue of morale, the provision of compensation also greatly affects employee performance, the problems found in compensation are that there are still employees who feel they are not in accordance with the bonus given by the company for work completed and there are still employees who are not satisfied with the incentives given by the company which exceeded normal working hours or overtime.

\section{Research Methods}

\subsection{Definition of Work Spirit}

Work spirit is the mental attitude of an individual or group that shows enthusiasm to carry out his work so that it encourages to be able to work together and be able to complete tasks on time with a sense of responsibility towards the work assigned to him.

Hasibuan (2008) states that work spirit is the desire and sincerity of someone to do well and be disciplined to achieve maximum work performance. Tohardi (2008), Work spirit is the ability of a group of people to work together actively and consistently in pursuing shared goals. 
From some of the opinions mentioned above, it can be said that basically the spirit of work is a condition that arises from within an individual that causes the individual or human being to do work in a happy atmosphere so that they work diligently, quickly, and better.

\subsection{Work Morale Indicators}

Work spirit is not always present in employees. Sometimes morale can also decrease. Indications of decreased morale are always there and indeed in general can occur. According to Nitisemito, quoted again by (Tohardi, 2008: 431), indications of a decline in employee morale include the following:

1. Low work productivity

According to him, productivity can occur due to laziness, delaying work, and so on. If there is a decrease in productivity, then this means an indication in the organization that there has been a decline in morale.

2. Absence rates are high and high

In general, when morale decreases, the employee is overcome with a feeling of being lazy to work. Moreover, the compensation or wages they receive are not subject to deductions when they are absent from work. Thus it can lead to the use of free time to get a higher income, even if only temporarily.

3. Labor turn over or a high rate of employee movement

Increased employee turnover is mainly due to employees experiencing displeasure when they work, so they intend to even decide to find another place to work that is more in line with the reasons for looking for comfort in work. Managers must be aware of symptoms like this.

4. Increased damage rate

The increase in the level of damage actually shows that attention in the work is reduced. Besides that there can also be carelessness at work and so on. An increase in the level of damage is a strong enough indication that morale has declined.

5. Anxiety everywhere

Anxiety can take the form of discomfort at work, complaints and other matters. The disruption of employee comfort allows for continued behavior that can harm the organization itself.

6. Frequent demands

Demands are an expression of dissatisfaction, which at some stage will bring courage to submit guidance. The organization must be alert to mass demands on the part of employees.

7. Strikes

Strikes are a form of dissatisfaction, anxiety and so on. If this continues it will end with the emergence of demands and strikes.

\subsection{Compensation}

Someone who has collaborated in a company / organization is often referred to as human resources. The company / organization should give rights to the members of the company / organization in the form of compensation or compensation. Everything that an employee receives from that company is called compensation.

Compensation according to Sihotang (2007: 220) "Compensation is the overall arrangement of providing compensation for employees and managers in the form of both financial and goods and services received by each employee". 
According to Mutiara (2009: 84) compensation is all types of awards in the form of pocket money or not that are given to employees appropriately and fairly for their services in achieving company goals.

According to Handoko (2009: 245) compensation is giving to employees with payment as compensation for work carried out and as a motivator for the implementation of activities in the future.

\subsection{Compensation Indicators}

In this study, the researchers used compensation indicators stated by Husein Umar (2007: 16):

1. Salary, which is given by the employer to employees, whose receipts are routine and permanent every month even if they do not come to work, the salary will still be received in full.

2. Incentives, awards given to motivate workers to have high work productivity, are not fixed in nature.

3. Bonuses, i.e. payments that are given at the same time because they meet work goals.

4. Treatment, providing services in managing risks associated with employee health.

5. Insurance is risk management for losses, losses, benefits and legal liability to third parties arising from uncertain events.

\subsection{Performance}

Performance is a function of motivation and ability to complete tasks or work. A person should have a certain degree of willingness and ability. A person's willingness and skills are not effective enough to do something without a clear understanding of what is done and how to do it. Performance is a real behavior that is displayed by everyone as a work achievement generated by employees in accordance with their roles and institutions. Employee performance is the work of quality and quantity achieved by an employee in carrying out their duties in accordance with the responsibilities given to him (Mangkunegara 2009).

\subsection{Performance Indicators}

According to Suryadi Prawirosentono (2008: 27), employee performance can be assessed by several indicators, namely:

1. Quality. Work quality is measured by employee perceptions of the quality of work produced and the perfection of the task of the skills and abilities of employees

2. Quantity. Represents the amount produced expressed in terms such as the number of units, the number of activity cycles completed

3. Timeliness. Represents the level of activity completed at the beginning of the stated time, viewed from the point of coordination with the output results and maximizes the time available for the activity

4. Effectiveness. Is the level of use of organizational resources (energy, money, technology, raw materials) maximized with the intention of increasing the results of each unit in the resource.

5. Independence. Is the level of an employee who later will be able to carry out the work function of work commitments. Is a level where employees have a commitment to work with the agency and employee responsibilities to the office. 


\subsection{Hypothesis}

According to Sugiyono (2012: 81) "Hypothesis is a guess or reference that is formulated and accepted for a while that can explain the facts that are observed and used as a guide in decision making".

1. Work spirit partially has a positive effect on the performance of the employees of PT. Arista Auto Lestari Medan.

2. Partial compensation has a positive effect on the performance of employees of PT. Arista Auto Lestari Medan.

3. Working morale and compensation simultaneously have a positive effect on the performance of the employees of PT. Arista Auto Lestari Medan.

\section{Research Methods}

This type of research is associative, according to Sugiyono (2012: 11), an associative approach is an approach using two or more variables to determine the relationship or influence of one with another. The population of this study is all employees of PT. Arista Auto Lestari Medan as many as 65 people. The whole sample is used in this study.

\subsection{Multiple Linear Analysis}

\section{Discussion}

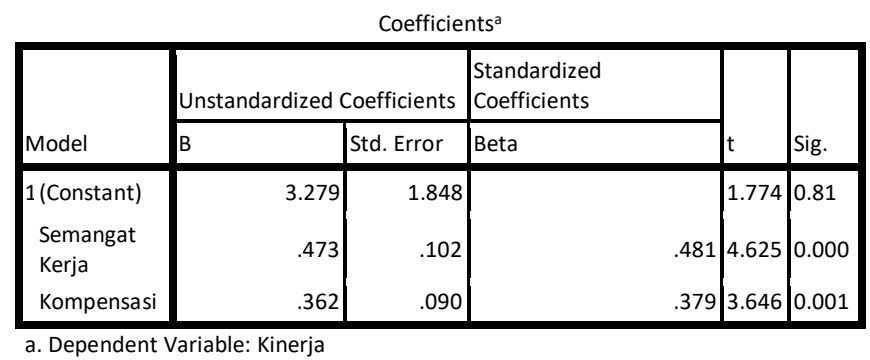

Regression coefficients were obtained:

$$
\begin{aligned}
& y=a+b 1 X 1+b 2 X 2+e \\
& y=3.279+0.473 X 1+0.362 X 2+e
\end{aligned}
$$

The constant value obtained is 3,279 if the morale variable $\left(\mathrm{X}^{1}\right)$ and the compensation variable $\left(\mathrm{X}^{2}\right)$ are constant then the performance variable $(\mathrm{Y})$ is worth 3,279 .

The coefficient of work morale variable $\left(\mathrm{X}^{1}\right)$ obtained value of 0.473 , this shows that every change in morale variable $\left(\mathrm{X}^{1}\right)$ of $1 \%$ will affect the performance $(\mathrm{Y})$ of $47.3 \%$ assuming the compensation variable $\left(\mathrm{X}^{2}\right)$ is considered fixed.

The coefficient of compensation variable $\left(\mathrm{X}^{2}\right)$ is obtained value of 0.362 , this shows that every change in the compensation variable (X2) of $1 \%$ will affect the performance (Y) of $36.2 \%$ assuming the morale variable $\left(\mathrm{X}^{1}\right)$ is considered permanent.

\subsection{Hypothesis testing Partial Test (Test $\mathbf{t}$ )}

Based on the partial hypothesis test results in table IV.22 above can be explained as follows:

1. Free Variable X1 (Work Spirit) 
$\mathrm{T}_{\text {count }}$ value obtained 4.625 where the value of $\mathrm{t}_{\text {table }}$ at $\alpha 5 \%$ i.e. 1.670 means positive. Where the significant level $\alpha 5 \%$ value of $t_{\text {count }} 4,625>t_{\text {table }} 1,670$. This explains that morale has a positive effect on the performance of the employees of PT. Arista Auto Lestari Medan.

The p-value in column sig $0.000<0.005$ means that it is significant. This explains that morale has a significant effect on the performance of the employees of PT. Arista Auto Lestari Medan.

2. Free Variable $\mathrm{X} 2$ (Compensation)

$\mathrm{T}_{\text {count }}$ value obtained 3.646 where the value of $\mathrm{t}_{\text {table }}$ at $\alpha 5 \%$ ie 1.670 means positive. Where the significance level of $\alpha 5 \%$ value of $t_{\text {count }} 3,646>t_{\text {table }} 1,670$ this explains that compensation has a positive effect on the performance of employees of PT. Arista Auto Lestari Medan.

The p-value in column sig $0.001<0.005$ means that it is significant. This explains that compensation can significantly influence the performance of employees of PT. Arista Auto Lestari.

\section{F Test (Partial)}

ANOVA $^{\mathrm{b}}$
\begin{tabular}{|ll|l|l|l|l|l|}
\hline Model & & $\begin{array}{l}\text { Sum of } \\
\text { Squares }\end{array}$ & $\mathrm{df}$ & $\begin{array}{l}\text { Mean } \\
\text { Square }\end{array}$ & $\mathrm{F}$ & Sig. \\
\hline 1 & \begin{tabular}{ll|l|l|l|} 
Regressi \\
on
\end{tabular} & 94.279 & 2 & 47.139 & 48.7 & $.000^{\mathrm{a}}$ \\
& $\begin{array}{l}\text { Residual } \\
\text { Total }\end{array}$ & 59.936 & 62 & .967 & 62 & \\
& 154.215 & 64 & & & \\
\hline
\end{tabular}

a. Predictors: (Constant), Compensation, Work Spirit

b. Dependent Variable: performance

The value of $F_{\text {count }}>F_{\text {table }}$ obtained $48.762>3.15$ means positive. While the p-value obtained in the sig column $0.000<0.05$ means that it is significant. Thus it can be concluded that work morale and compensation can simultaneously have a positive and significant effect on the performance of employees of PT. Arista Auto Lestari Medan

\section{Koefisien Determinasi.}

\begin{tabular}{l|r|r|r|r|}
\hline $\begin{array}{l}\text { Mode } \\
\mathbf{l}\end{array}$ & $\mathbf{R}$ & $\mathbf{R}$ Square & $\begin{array}{c}\text { Adjusted R } \\
\text { Square }\end{array}$ & $\begin{array}{c}\text { Std. Error } \\
\text { of the } \\
\text { Estimate }\end{array}$ \\
\hline 1 & $0.782^{\mathrm{a}}$ & 0.611 & 0.599 & 983 \\
\hline
\end{tabular}
a. Predictors: (Constant), Work spirit and
Compensation
b. Dependent Variable: performance

Based on the calculation of the coefficient of determination, it can be seen the value of R Square obtained by 0.599 . This figure shows that $59.9 \%$. Performance (the dependent variable) can be explained by the variable morale and compensation. The remaining $40.1 \%$ is influenced by other factors not explained in this study. 


\section{Conclusions}

From the results of exposure and discussion of the data above, the conclusions from research results are:

1. Independent Variable $\mathrm{X} 1$ (Work Spirit) $\mathrm{T}_{\text {count }}$ obtained 4.625 where the value of $t_{\text {table }}$ at $\alpha$ $5 \%$ i.e. 1.670 means positive and the p-value in the column sig $0.000<0.005$ means significant. This explains that morale has a significant effect on the performance of the employees of PT. Arista Auto Lestari Medan.

2. Independent Variable $X 2$ (Compensation) obtained $t_{\text {count }}$ obtained 3,646 where the value of $t_{\text {table }}$ at $\alpha 5 \%$ i.e. 1,670 means positive and p-value in column sig $0.001<0.005$ means significant. This explains that compensation can significantly influence the performance of the employees of PT. Arista Auto Lestari Medan. From the results of the hypothesis t test it is known that the morale variable is more influential than the compensation variable.

3. Based on the results of the study simultaneously the value of $F_{\text {count }}>F_{\text {table }}$ obtained 48,762> 3.15 means positive. While the p-value obtained in the sig column $0.000<0.05$ means that it is significant. Thus it can be concluded that work morale and compensation simultaneously can have a positive and significant effect on the performance of employees of PT. Arista Auto Lestari Medan

4. Based on the calculation of the coefficient of determination, the R Square value obtained is 0.599. This figure shows that $59.9 \%$. Performance (the dependent variable) can be explained by the variable work motivation and compensation. The remaining $40.1 \%$ is influenced by other factors not explained in this study.

\section{References}

Achmad Sanusi. dan M. Sobry Sutikno. (2009), kepemimpinan sekarang dan masa depan dalam membentuk budaya organisasi yang efektif, Jakarta. Prospect

Arep, Ishak dan Hendri, Tanjung. (2008). Manajemen Sumber Daya Manusia. Jakarta: Universitas Trisakti.

Armstrong, Michael. (2009). Armstrong's Handbook of Human Resource ManagementPractice. London: Kogan Page

Fadhil Masyhura. (2009). "PengaruhPengawasan Atasan Dan Kompensasi Terhadap Disiplin Kerja Karyawan PT.Jamsostek (Persero) Cabang Sumatera Barat, Fakultas Ekonomi Universitas Negeri Padang"

Ghozali, Imam. (2006). Aplikasi Analisis Multivariate dengan Program SPSS. Badan Penerbit Universitas Diponegoro : Semarang.

Hasibuan, Malayu S.P. (2006), Manajemen Dasar, Pengertian, dan. Masalah,Edisi Revisi, Bumi Aksara:Jakarta

Ivancevich, J.M., Konopaske, R. dan MattesonM.T. (2006). Perilaku dan ManajemenOrganisasi. Jilid 1 dan 2. Edisi ketujuh.Erlangga, Jakarta

Kreitner,Robert dan Kinicki, Angelo. (2008), Perilaku Organisasi. Edisi pertama.buku 1. Salemba Empat, Jakarta.

Kusawati, Y. (2019). Motivation Role in Improving Work Effectiveness. Budapest International Research and Critics Institute (BIRCI-Journal), 281-288.

Mangkunegara, AA. Anwar Prabu. 2009.Manajemen Sumber Daya Manusia Perusahaan, Remaja Rosdakarya, Bandung. 
Mondy, R. Wayne. (2008). Manajemen Sumber Daya Manusia, Edisi Kesepuluh, Jilid I, Penerbit Erlangga, Jakarta.

Sedarmayati. (2009). Sumber Daya Manusia dan Produktinitas Kerja, CV Mandar Maju, Bandung

Siagian Sondang P. (2008), Manajemen Sumber Daya Manusia, Cetakan Kelima Belas, Penerbit Bumi Aksara, Jakarta

Sugiyono. (2006). "Metode Penelitian Bisnis". Alfabeta, CV : Bandung

Tika, MP. (2006).Budaya Organisasi dan Peningkatan Kinerja Perusahaan. Jakarta :Bumi Aksara

Winda Novelya Sinaga. (2014). Pengaruh Motivasi, dan Semangat Kerja Terhadap Kinerja Pegawai PT. PLN (PERSERO) Kantor Regional Wilayah Riau dan kepulauan Riau. Dalam jurnal Ekonomi Bisnis

Sudarto Widyo.(2002). Pengaruh promosi jabatan Terhadap kinerja pegawai negeri sipil di dinas energy dan sumber daya mineral propinsi bengkulu. Dalam jurnal Ekonomi Bisnis 